\title{
Interactive comment on "Chemical and microbiological characterization of primary biological aerosol particles at the boreal forest" by Jose Ruiz-Jimenez et al.
}

\section{Pierre Amato}

pierre.amato@univ-bpclermont.fr

Received and published: 1 December 2020

This work reports the size-resolved characterization of aerosol particles collected in a forested area in Finland (SMEAR II station). Samples were collected using cascade impactors and the different size fractions ( $<1 \mu \mathrm{m}, 1-2.5 \mu \mathrm{m}, 2.5-10 \mu \mathrm{m}$ and $>10 \mu \mathrm{m})$ were analyzed independently for amino acids, saccharides, total DNA and total fungi, total bacteria and Pseudomonas, along with COVs measured online, with an attempt to disentangle the contribution of biological particles (PBAP) to the chemical content. In general, highest values are found in the 2.5-10 $\mu \mathrm{m}$ size. The data were combined with meteorological variables and analyzed through several statistical approaches (correla- 
tion, regression, clustering), in order to reveal trends involving PBAP.

General comments:

- The dataset is interesting and original. This was analyzed through statistics, looking for trends between the different size fractions and between the different variables investigated, which is rather consistent with the underlying objective to identify a signature of specific PBAP. However, the absolute values themselves are neither discussed nor positioned respect to literature. It would be interesting to have a paragraph for discussing these, independently from trends.

- The title is probably too general and somehow inappropriate, as this is more about the interrelationships between variables than about the characterization itself. Also, is there any evidence that the particles looked for are indeed exclusively primary? and biological?

- Figure 1 and/or Tables S8-S11 could include a line with the sum of all fractions, which would thus correspond to the total aerosols load.

- I have a major concern with qPCR data, and these are fundamental in this study. First, there is not even a mention of the genes targeted. Second, and most importantly, the results: values around 1-10 genes (supposedly $16 \mathrm{~S}$ and $18 \mathrm{~S} \mathrm{rRNA}$ )/m3 of air are reported, indicating the presence of $10 \mathrm{cells} / \mathrm{m} 3$ at the very most, which is absolutely not consistent when the literature reports orders of magnitude higher values around 105-106 copies/m3 in much more remote contexts (see notably (Dommergue et al., 2019; Šantl-Temkiv et al., 2017; Tignat-Perrier et al., 2019, 2020). Even the same authors reported incomparable values in previous publication (Helin et al., 2017), so either the data themselves are not valid as they largely underestimate the actual situation, or it could be that the unit used is wrong, or again that there was a mistake in the conversion to air volumes. It would also be interesting to have indicated somewhere the cycle thresholds used for quantifications. 
- This work is basically a repeat (improved?) of that published in 2017 by Helin et al, with different approaches and added with new variables like saccharides. There are at several occasions (auto)-plagiarism of this reference in the experimental section (maybe acceptable there (?)). - The later reference is barely cited in the results and discussion section. However the present work would probably benefit to be positioned in context, with the findings discussed respect to previous ones.

Interactive

comment

- The choice of targeting in particular Pseudomonas among the humongous biodiversity that exists in the air must be justified. This is probably not obvious for everyone... Also, it might be useful to specify that Pseudomonas is a genus of bacteria at least in the introduction, this might not be obvious for every readers of ACP and it is presented as a distinct category.

- Unless I missed something, Table S1 and Figure 1 and Tables S8-S11 are the same data. However there are many inconsistencies, for instance the max values indicated for DNA, Pseudomonas and AA appear different from those in the figure. Can you check for any error and make the appropriate corrections.

- There is no mention of the results concerning control filters used for correcting chemical data: can you provide some information on what was found, if any contaminant was detected, and how the correction was done? Were there any such controls for microbiology (in addition of negative qPCR controls)?

Specific comments:

- L21 and throughout the manuscript: Specify which gene when mentioning gene copy numbers as it has no sense without this information.

- In Figure 1, the labels PM 2.5 and PM 10 are misleading as these are actually not $P M 2.5$ or $P M 10$ in the sense $P M<2.5$ or $<10$, but rather PM1-2.5 and PM2.5-10.

- L34: ". . the influence of microbes. ..": The term "influence" suggests active intervention, is this what is meant? or does this rather refer to the contribution to the pool of

Printer-friendly version

Discussion paper 
chemical compounds? This should be clarified by modifying "influence" if appropriate.

- L58: What is meant by "the role of amino acids in the atmosphere"? "impact" might be more appropriate?

- L77: "Viruses can be frequently found in the airborne..." state? (word missing)

Interactive

- Section 2.3: the latin names of trees must be italicized.

- L 193-195: italicize latin organisms' names

- L233: Pearson correlations were used. Was/how the normality of data verified?

- Section 3.6: (link between microbiology and VOC): aerosols for microbiological analyses were collected at $23 \mathrm{~m}$, above the canopy, while VOCs were screened by PRT-MS inside the canopy at $8.4 \mathrm{~m}$ above ground. Why this discrepancy? And how could this had influenced the data? It is known that above-canopy and below-canopy air can be decoupled and can have different signatures (Gabey et al., 2010; Jocher et al., 2020).

References:

Dommergue, A., Amato, P., Tignat-Perrier, R., Magand, O., Thollot, A., Joly, M., Bouvier, L., Sellegri, K., Vogel, T., Sonke, J. E., Jaffrezo, J.-L., Andrade, M., Moreno, I., Labuschagne, C., Martin, L., Zhang, Q. and Larose, C.: Methods to investigate the global atmospheric microbiome, Front. Microbiol., 10, doi:10.3389/fmicb.2019.00243, 2019.

Gabey, A. M., Gallagher, M. W., Whitehead, J., Dorsey, J. R., Kaye, P. H. and Stanley, W. R.: Measurements and comparison of primary biological aerosol above and below a tropical forest canopy using a dual channel fluorescence spectrometer, Atmospheric Chemistry and Physics, 10(10), 4453-4466, doi:10.5194/acp-10-4453-2010, 2010.

Helin, A., Sietiö, O.-M., Heinonsalo, J., Bäck, J., Riekkola, M.-L. and Parshintsev, J.: Characterization of free amino acids, bacteria and fungi in sizesegregated atmospheric aerosols in boreal forest: seasonal patterns, abundances 
and size distributions, Atmospheric Chemistry and Physics, 17(21), 13089-13101, doi:https://doi.org/10.5194/acp-17-13089-2017, 2017.

Jocher, G., Fischer, M., Šigut, L., Pavelka, M., Sedlák, P. and Katul, G.: Assessing decoupling of above and below canopy air masses at a Norway spruce stand in complex terrain, Agricultural and Forest Meteorology, 294, 108149, doi:10.1016/j.agrformet.2020.108149, 2020.

Šantl-Temkiv, T., Amato, P., Gosewinkel, U., Thyrhaug, R., Charton, A., Chicot, B., Finster, K., Bratbak, G. and Löndahl, J.: High-Flow-Rate Impinger for the Study of Concentration, Viability, Metabolic Activity, and Ice-Nucleation Activity of Airborne Bacteria, Environ. Sci. Technol., 51(19), 11224-11234, doi:10.1021/acs.est.7b01480, 2017.

Tignat-Perrier, R., Dommergue, A., Thollot, A., Keuschnig, C., Magand, O., Vogel, T. M. and Larose, C.: Global airborne microbial communities controlled by surrounding landscapes and wind conditions, Sci Rep, 9(1), 1-11, doi:10.1038/s41598-019-510734, 2019.

Tignat-Perrier, R., Dommergue, A., Thollot, A., Magand, O., Amato, P., Joly, M., Sellegri, K., Vogel, T. M. and Larose, C.: Seasonal shift in airborne microbial communities, Science of The Total Environment, 716, 137129, doi:10.1016/j.scitotenv.2020.137129, 2020.

Interactive comment on Atmos. Chem. Phys. Discuss., https://doi.org/10.5194/acp-2020-1065, 2020. 